\title{
Public Health Implication of Shared Toys Amongst Children Age 1-5 Years Attending Crech and Nursery Schools within the Cross River State Region. A Case Study in Calabar Metropolis
}

\author{
Usang Akedor ${ }^{1}$, Ekeng Ita $^{2}$, Victoria Okon ${ }^{3}$, Boniface Ati ${ }^{4}$, \\ Michael Adegbenro ${ }^{5}$
}

\author{
${ }^{1}$ Department of Medical Laboratory Science, College Of Health Technology, Calabar \\ ${ }^{2,3}$ Department of Environmental Health,College of Health Technology Calabar \\ ${ }^{4}$ Department of Medical Laboratory Science, College of Health Science and Technology, Ekiti
}

\begin{abstract}
A fundamental aspect of child growth is playfare hence toys come in handy. Cognitive development in children is largely a product of quality engagement at playtime (Alfred, 2015). The ability of microbes to colonize the hands and in extension everything or object it contacts is legendary (Usang,2013). Twenty toys commonly used by children were sampled from ten (10) nursery and Creche Schools in Calabar Metropolis. Toys from four (4) schools were found to harbor pathogenic microbes suggesting their potency as vehicles of disease transmission disease causing microbes isolated range between bacteria and fungi amongst which are Escherichia Coli; Staphylococcus aureus, Proteus Spp, and Candida Albicans. The study has established the ability of toys to convey disease causing microbes, if healthy sanitary conditions are not regularly maintained, hence the recommendations for the need for proper hygiene among school children and children handlers or teachers teaching of regular handwashing protocol to children of school growing age and regular sanitization of hand held toys amongst others.
\end{abstract}

\section{INTRODUCTION}

Play time is one of the most fundamental parts of childhood development. Children play in variety of ways, and with a number of different toys. Toys and other objects are important extension of a young child. Children have play with toys throughout history and in all creatures.

Play time is fun. Young children love to explore and discover new things about the world around them and about themselves (Jeffrey, 2012). Toys have a role in children development, playing with toys is an enjoyable means of training the young for life in society (Wash, 2005).

Toys are vital tools and help foster the mental, physical and social well-being of children. Toys are basic instrument for the development of children fantasy, thought and creativity. Children gain a strong foundation for learning through play. Toys sharing among children played significant role in engaging children senses, spark their imagination, enable them to interact with one another, help them discover their identity, helps their body grow strong, helps them learn cause of effectiveness, helps them explore relationship and practice skills.

\begin{abstract}
Since children share toys, especially in schools, as some of these toys are used in teaching them, they also get exposed to public health problem despite its lucrative benefits to them (children). As children share toys together it is possible that disease can be transmitted from one child to another through the toy(s). For example, a child that has common cold and is experiencing runny noise can transmit the causative agent to another child if the shared toys come into contact with the mucus and since children easily pick things and put them directly into their mouth, the child can be infected. Also some of them rub their toys on the ground and then pick them and put directly into their mouths, thus ingesting path organic organisms into their bodies. (Ellen, 2013) The question is: Are there pathogenic microbes on fomites in crèche and nursery school classes in Calabar Metropolis? What is the most common pathogenic microbe on fomites in crèche and nursery school classes in Calabar Metropolis? This study attempts to examine these questions.
\end{abstract}




\section{MATERIALS AND METHODS}

The study area of this research is Calabar Metropolis.It is a cosmopolitan area being the capital of Cross River State of Nigeria.

Calabar Metropolis has an area of $604 \mathrm{~km}^{2}$ and is located between latitudes $4^{0} 57^{\prime} \& 4.95^{\circ} \mathrm{N}$ and longitudes $8^{0} 19^{\prime} \& 8.317^{\circ} \mathrm{E}$. Its limit does not extend beyond welcome to Calabar in the north, Ekpo Abasi junction in the south, Atimbo in the east and the Calabar River in the west.

Calabar is located in the Tropical rain forest climate region with marked wet and dry seasons. Temperature is high all year round with average daily temperature of $32^{\circ} \mathrm{c}$. The city experience nine months of rainfall with annual precipitation of about $588 \mathrm{~mm}$.

Calabar has a large urban setting with few pockets of sub-urban or semi urban areas. It has a predominantly Christian population, majority of who are public servants, business men and artisans. Calabar is cosmopolitan in nature with education at all levels taking a prime place in the activities of the people. It has two government Universities, more than one hundred Secondary Schools and more than three hundred Crèches/Nursery/Primary Schools.

Ten(10) schools were selected from the 302 nursery schools and crèches in Calabar and from the 10 nursery and crèches schools in Calabar, twenty (20) toys were randomly selected as follows: God's Grace Nursery and Primary School (2) samples, Trinity Group of Schools (2) samples, Living Stone Academy (2 samples) Light House Nursery and Primary School (2) samples, Calabar preparatory Nursery and Primary School (2) samples, Bluebells Nursery and Primary school (2) samples, Aknes International School (2) samples, De Wisdom Nursery and Primary School (2) samples, Herons International School (2) samples, and (2) samples from Etim Ekong Nyong Nursery and Primary School; all making a total number of twenty (20)

Ethical consideration was sought for and obtained from different schools.

Samples were collected from toys in Nursery Schools and Crèches using moisturized sterile cotton swabs and they were transferred immediately to the laboratory for analysis. Standard microbiological procedures and techniques were employed in the culture, isolation and identification of implicated microorganisms.

\section{Method}

1) Prepare agar (e.g nutrient agar and MacConkey agar).

2) Pour molten agar into sterile Petri dishes and allow setting.

3) Dry agar in oven at the temperature of 35 to

$40^{\circ} \mathrm{C}$. Check often and do not allow to melt.

4) Ascetically inoculate sample into dehydrated agar using sterile wire loop.

5) Allow for 18-24 hours in the incubator then read plate.

6) Implicated organism are isolated using appropriate techniques e.g Gram stain for morphological identification, biochemical test for biochemical identification and other physiological method e.g motility test.

7) From the above an inference is arrived at of the implicating organism e.g E. coli, staphylococcus aureus etc.

\section{Principles}

The following principles were used for the research:

1) Incubation at $37^{\circ} \mathrm{c}$ creating an ambient (condition similar to that natural condition in human body allows for the growth of microorganism as there would have in the human body.

2) Grams staining principle;

Grams positive posses a thick cell wall and will accept primary stain (crystal violet) without losing it after discoloration.

Gram negative posses a thin cell wall which will accept primary stain crystal violet but readily lose it on application of a decolorizer to take up the counter stain safrani, neutral red or dilute carbolifuschin.

\section{Method of data analysis}

After the experiment is carried out, simple Percentage was adopted for analysis of data.

\section{Limitation of the study}

Non-cooperation from schools authorities; time for the work was not sufficient; it was difficult combining the experimental research work with other academic programme; due to economic status of the country I could not get enough for the work.

\section{RESULTS}

Twenty Toys from ten (10) nursery and crèche schools in Calabar Metropolis were analyzed for microbial presence. Toys from four (4) schools were found to have microbial contaminants capable of posing public health danger, if such toys are shared. The results are therefore presented below; 
Public Health Implication of Shared Toys Amongst Children Age 1-5 Years Attending Crech and Nursery Schools within the Cross River State Region. A Case Study in Calabar Metropolis

Table I: Showing the total number of samples collected and microbes (organisms) isolated from nursery and crèche in Calabar Metropolis

\begin{tabular}{|l|l|l|}
\hline Schools & Samples collected & Organisms Isolated \\
\hline A & A1 & Escherichia coli \\
& A2 & Escherichia coli \\
\hline B & B1 & Escherichia coli \\
& B2 & Escherichia coli \\
\hline C & C1 & No Microbes \\
& C2 & No Microbes \\
\hline D & D1 & Staphylococcus aureus \\
& D2 & No Microbes \\
\hline E & E1 & Staphylococcus aureus \\
& E2 & No Microbes \\
\hline F & F1 & Proteus Spp \\
& F2 & No Microbe \\
\hline G & G1 & No Microbes \\
& G2 & No Microbes \\
\hline H & H1 & No Microbes \\
& H2 & No Microbes \\
\hline I & I1 & No Microbes \\
& I2 & No Microbes \\
\hline J & J1 & Candida albican \\
& J1 & No Microbes \\
\hline
\end{tabular}

Source: Laboratory analysis, 2017

Table II: Showing the presence or absence of different microbes (bacteria, fungi and parasites) on school toys

\begin{tabular}{|l|l|l|l|}
\hline School & \multicolumn{2}{|c|}{ Microbe } & Pungi \\
\hline & Bacteria & No microbes & No Microbes \\
\hline A & Escherichia Coli (2) & No microbes & No Microbes \\
\hline B & Escherichia Coli (2) & No microbes & No Microbes \\
\hline C & No microbes & No microbes & No Microbes \\
\hline D & Staphylococcus aureus (1) & No microbes & No Microbes \\
\hline E & Staphylococcus aureus (1) & No microbes & No Microbes \\
\hline F & Proteus & No microbes & No Microbes \\
\hline G & No microbes & No microbes & No Microbes \\
\hline H & No microbes & No microbes & No Microbes \\
\hline I & No microbes & Candida albican & No Microbes \\
\hline J & No microbes & \\
\hline
\end{tabular}

Source: Laboratory analysis, 2017

Table III: Showing physiological and Biochemical Identification of Bacteria Present

\begin{tabular}{|c|c|c|c|c|c|c|c|c|c|c|}
\hline \multirow{2}{*}{ 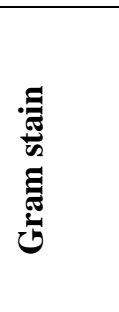 } & \multirow{2}{*}{ 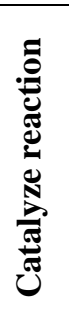 } & \multirow{2}{*}{ 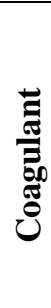 } & \multirow{2}{*}{$\frac{0}{\underline{\theta}}$} & \multirow[b]{2}{*}{$\stackrel{\Xi}{\Xi}$} & \multicolumn{4}{|c|}{ KIA } & \multirow{2}{*}{ 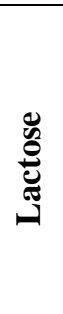 } & \multirow{2}{*}{ 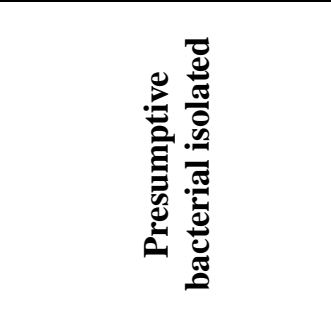 } \\
\hline & & & & & $\mathbf{Y}$ & $\mathbf{R}$ & 包 & $\mathbf{H}_{2} \mathbf{S}$ & & \\
\hline$-\operatorname{rod}$ & - & - & + & + & + & - & - & - & + & Escherichia coli \\
\hline$-\operatorname{rod}$ & - & - & + & + & + & - & - & - & + & Escherichia coli \\
\hline+ cocci & + & + & - & - & - & - & - & - & - & Staphylococcus qureus \\
\hline$-\operatorname{rod}$ & - & - & - & + & + & + & - & - & - & Proteus spp \\
\hline
\end{tabular}

Source: Laboratory analysis, 2017 
Public Health Implication of Shared Toys Amongst Children Age 1-5 Years Attending Crech and Nursery Schools within the Cross River State Region. A Case Study in Calabar Metropolis

Key:

$-\operatorname{rod}=$ Gram negative rod

+ cocci $=$ Gram positive cocci

Cracking $=$ Gas production

$\mathrm{Y}=$ Yellow colour production

$\mathrm{R}=$ Reddish colouration

$\mathrm{H}_{2} \mathrm{~S}=$ Hydrogen sulphide production

Table IV: Showing physiological and biochemical identification of fungal organisms present

\begin{tabular}{|ll|l|l|l|l|}
\hline $\begin{array}{l}\text { Gram stain } \\
\text { (indirect) }\end{array}$ & $\begin{array}{l}\text { Growth on } \\
\text { saboroad } \\
\text { Dextrose Agar }\end{array}$ & Germ tube test & $\begin{array}{l}\text { Calcoflor white } \\
\text { stain }\end{array}$ & Fungi present \\
\hline $\begin{array}{l}\text { Yeast cells stain } \\
\text { purple }\end{array}$ & $\begin{array}{l}\text { Growth of white- } \\
\text { yellowish large } \\
\text { and intercalated } \\
\text { colonies after } \\
\text { incubation at } 37^{\circ} \mathrm{c} \\
\text { for } 18 \text { hours }\end{array}$ & $\begin{array}{l}\text { Sprouting yeast } \\
\text { cells seen }\end{array}$ & & Candidiabican \\
\hline
\end{tabular}

Source: Laboratory analysis, 2017

Table V: Showing percentage representation of Isolates

\begin{tabular}{|l|l|l|}
\hline Sample collected & Organisms Isolated & Percentage (\%) \\
\hline A & Escherichia coli & $2(2 / 8 \times 100 / 1) 25 \%$ \\
\hline B & Escherichia coli & $2(2 / 8 \times 100 / 1) 25 \%$ \\
\hline C & No microbes & \\
\hline D & Staphylococcus aureus & $1(1 / 8 \times 100 / 1) 12.5 \%$ \\
\hline E & Staphylococcus aureus & $1(1 / 8 \times 100 / 1) 12.5 \%$ \\
\hline F & Proteus spp & $1(1 / 8 \times 100 / 1) 12.5 \%$ \\
\hline G & No microbes & \\
\hline H & No microbes & \\
\hline I & No microbes & \\
\hline J & Candida albican & $1(1 / 8 \times 100 / 1) 12.5 \%$ \\
\hline Total & & $100 \%$ \\
\hline
\end{tabular}

Source: Laboratory analysis, Source: Laboratory analysis, 2017

Fig 1: Bar chart showing Frequency of Isolation of fungal and parasite organism

\section{Isolates}

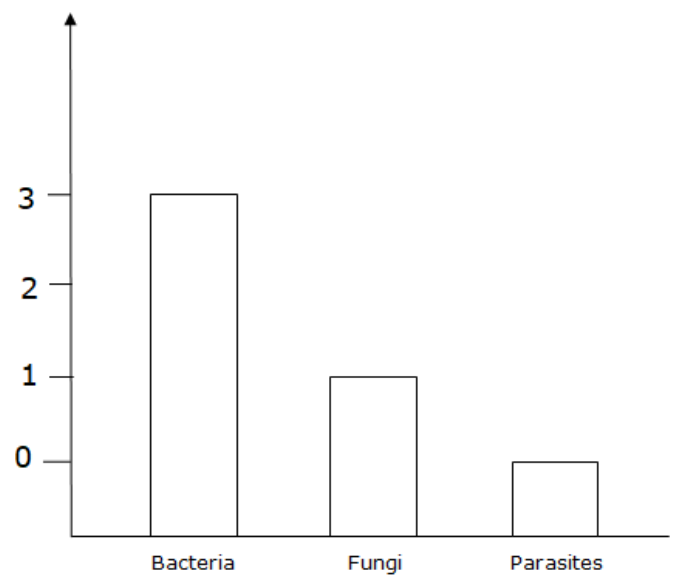

Fig II: Bar chart showing Frequency of bacterial isolates

\section{Frequency of Isolates}

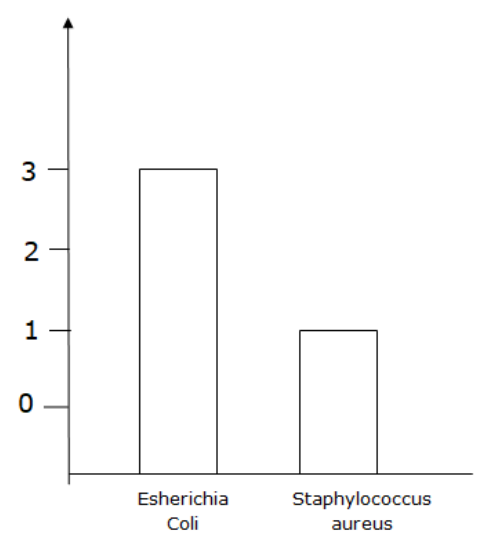


Fig III: Pie chart showing the degree of Isolates to non isolates

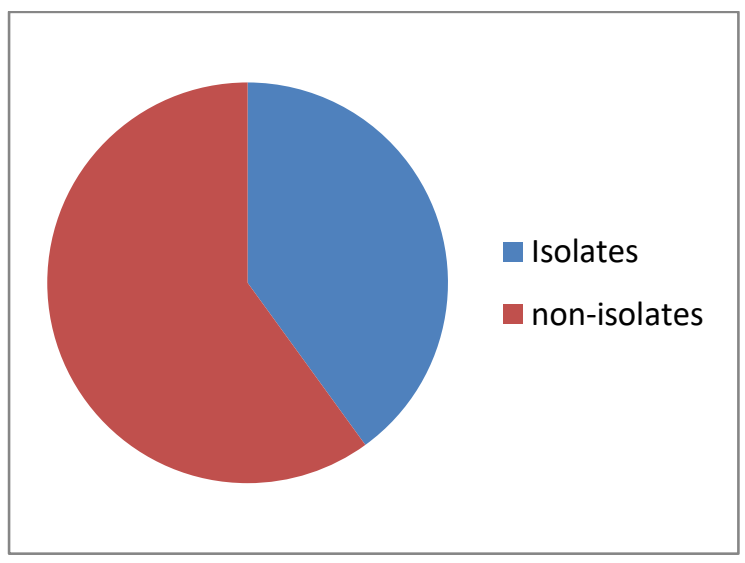

\section{DISCUSSION}

The ability of children and infants to acquire infection is far higher than in adults (Alyssa et al, 2011). Most children in the $21^{\text {st }}$ century are even more exposed and early in life, given that they have to mix with the public at a very early age. Children are registered at nursery and crèche schools as early six months (6 months) due to several factors, prominent among which is the fact that both parents are working class, hence cannot take the children along to office or cannot hire the services of a trusted nanny for home services.

Our hands are potent vehicle for microbial transmission from one person to another (Usang, 2013). Most public acquired infection are through contaminated hands. It is therefore necessary to assess the microbial quality of shared toys, given that children have a low sanitary threshold (Alyssa et al, 2011) and may unwillingly pass infection from one child to another. It is also important to note that at a tender age children easily put materials in their mouths, hence increasing the risk of infection. (Curtis et al, 2009).

From table I: we see that out of the ten schools randomly sampled $4(40 \%)$ schools showed on had contaminated toys while $6(60 \%)$ schools had toys free of microbial contamination. These points to the fact that most of the schools take sanitary conditions, even if shared toys seriously, hence may have the tradition of constantly cleaning the toys. The results agree the work of Christine et al, 2013 who showed that a fewer number of the children toys sampled had any form of contamination in households with good sanitation. However, a work done by Christine et al, 2013 showed contamination on most of the children toys sampled in households with poor sanitation.

In table 2 more bacteria were isolated than fungi, which no parasite was isolated. This may be due to the fact that bacteria are generally more ubiquitous and fastitious; they multiply in every large number over a short period of time (Usang, 2013). The absence of parasites is in tandem with the work of Usang,2013, as parasites are known to be highly motile, less fastidious (especially when not in their Usacel site), hence may move from one place to another. However, a work by CDC, 2015 showed that parasites could be isolated from toys. Another reason why the parasites could not be isolated owes to the sensitivity of method used, probably a more sensitive method may recover parasites if present (Edward, 2008).

Table 3 shows the biochemical and physiological methods employed to arrive at a presumptive isolated of the various organisms. The methods are as numerated in the tropical laboratory practice by Monica Cheesbrough, 2000.

Table 4 shows methods for fungal isolation as enumerated in Lazarus etal, 2011.

\section{CONCLUSION}

The study showed that microbes can be isolated from shared toys if not properly or hygienically handled. The need for proper hygiene even among teachers is recommend in this work.

\section{RECOMMENDATIONS}

From the study, the following recommendations are highlighted below;

1. The need for proper hygiene among school children is needed

2. Children shared toys should be cleaned or sanitized to prevent contaminants being passed from one child to another.

3. Children handlers/teachers who come in contact with these toys must maintain high hygiene standards.

4. Regular hand washing practices should be taught and practiced in nursery schools and crèche.

\section{REFERENCES}

1. Alyssa Vivas, Bizu Gelaye, Nigusu Aboset Abera Kumie, Yemune Berhane and Michelle A. Williams (2011) Journal of Preventive Medicine and Hygiene. www.ncbi.nlm.nih.gov.

2. Barrie D., et al. contamination of hospital lien by Baccillus cereus. Epidemio infect. 1994 Oct; 113 92): 297-306 (PMC free article) (pubmed)

3. Bettye M, Caldwd (2017). Importance of toys in early childhood development. Article http://www.fisher price/.com/en-US/patenting-articles/playtime-and toys/importance-of-play-inearly-childhood education.

4. CDC-Lice-HeadLice - General Information-Malathia FAQS (2015). http://www.cdc.gov.General information.

5. Christine E. Stauber, Adams Walters, Anna Fabis Zewski \& Mark D. Sobey (2013) Bacterial Contamination Household Toys and Assoc. with $\mathrm{H}_{2} \mathrm{O}$ Sanitary fellowship.

6. Christine E. Stauber, Adams Walters, Anna Fabiszewki and Mark D. Sobey (2013). Bacterial Contamination on House 
Public Health Implication of Shared Toys Amongst Children Age 1-5 Years Attending Crech and Nursery Schools within the Cross River State Region. A Case Study in Calabar Metropolis

Condition in Honduras. International Journal of Environmental Research

7. Curtis VA, Danquah LO, Aunger RV. (2001): Planned, Motivated and Habitual Hygiene behavior on Eleven Country Review. Health Educ. Res. 2009; 4:655-673.

8. Ellen Goldbaum (2013). News Center. University at Buffal. goldbaum@buffals.com

9. Etiene Benson (2006). Childhood parenting. https: //www.psychologicalscience.org/tag/sociocultural-factors.

10. Jeffrey Goldstain (2 012). Play in Children's Development Health and wellbeing. Oxford University Press.
11. Kenneth, R. Ginsburg (2011). Raising resilient children and teens. American Academy of Pediactrics $3^{\text {rd }}$ edition. Carleton Kendrick (2016). The importance of toys http://www.familyeducation.com

12. Monica Cheesbrough (2000). Laboratory Practice in Tropical Countries.

13. Rhame FS. The inanimate environment in Hospital infections: beneth JV, Branchman ps. editors. Little Brown and company (Inc) $3^{\text {rd }}$ edition 1992. pp-299-33.

14. Usang, Akedor I. (2013). Project Thesis on the Public Health Implication of Microbial Contamination of ATM Keypads in Calabar 